\title{
COMPARISON OF PROGRESSIVE COLLAPSE RESISTANCE OF FRAME WITH SPECIALLY SHAPED COLUMNS AND FRAME WITH RECTANGULAR COLUMNS
}

\author{
Qingwei Chen, Hailong Zhao, Tiecheng Wang
}

Original scientific paper

$\mathrm{RC}$ frame structures with specially shaped columns and RC frame structures with rectangular columns are different types of structures with different column sections. A progressive collapse analysis model of RC frames was proposed using the beam-column element and joint element based on the program OpenSees. Progressive collapse performance of the experimental frame was simulated and the calculation results were in good agreement with the experimental results. The characteristics of progressive collapse performance of frames with specially shaped columns were studied by comparing the progressive collapse resistance of one frame with specially shaped columns with that of three frames with rectangular columns which were designed in accordance with three different principles. It was observed from the results that the progressive collapse resistance of frame with specially shaped columns and frames with rectangular columns with the same reinforcement under the same seismic fortification, design and application conditions were equivalent. The frame with specially shaped columns had a superior performance to resist progressive collapse.

Keywords: frames with specially shaped columns; non-linear analysis; numerical simulation; progressive collapse

Usporedba otpora progresivnom kolapsu okvira s posebno oblikovanim stupovima i okvira s četvrtastim stupovima

Izvorni znanstveni članak

Konstrukcije okvira od armiranog betona (RC - reinforced concrete) s posebno oblikovanim stupovima i RC konstrukcije okvira s pravokutnim stupovima su različite vrste konstrukcija s različitim poprečnim presjecima stupova. Predlaže se model za analizu progresivnog kolapsa RC okvira primjenom elementa greda-stup i veznog elementa na temelju programa OpenSees. Simulirao se progresivni kolaps eksperimentalnog okvira i rezultati proračuna su se poklapali s rezultatima dobivenim eksperimentom. Karakteristike progresivnog kolapsa okvira s posebno oblikovanim stupovima analizirale su se usporedbom otpora progresivnom kolapsu jednog okvira s posebno oblikovanim stupovima i onog s tri okvira s pravokutnim stupovima koji su konstruirani u skladu s tri različita principa. Vidjelo se iz rezultata da su otpor progresivnom kolapsu okvira s posebno oblikovanim stupovima i okvira s pravokutnim stupovima s istom armaturom pod istim seizmičkim ojačanjem, konstrukcijom i uvjetima primjene bili jednaki. Okvir s posebno oblikovanim stupovima bolje je reagirao u otporu na progresivni kolaps.

Ključne riječi: ne-linearna analiza; numerička simulacija; okviri s posebno oblikovanim stupovima; progresivni kolaps

\section{Introduction}

Progressive collapse is defined as the spread of an initial local failure from element to element eventually resulting in collapse of an entire structure or a disproportionately large part of it [1]. Protection of life safety and preservation of residential function are always the main targets for structural analysis and design of buildings. A very basic mission for reaching the goals is to prevent the building structures from progressive collapse. Engineers and researchers started to pay attention to progressive collapse resistance of structures since the partial collapse of Ronan Point Apartment in England in 1968 resulting from a gas explosion. Widespread concerns of progressive collapse of structures have accelerated since the 911 event leading to the collapse of the New York World Trade Center twin towers [2]. A surge of research activities in evaluating the potential of buildings for progressive collapse, which is typically triggered by the missing of critical gravity loadbearing elements due to abnormal loading had been discussed in literature $[3 \div 5]$. Some study results, code approaches, and design strategies or standards have been reviewed, discussed, and/or compared in the literature $[6 \div 12]$. Marjanishvili and Agnew et al. made a comparison of various procedures for progressive collapse analysis by using the commercial finite element software SAP2000 [13, 14]. Detailed descriptions of a step-by-step, linear static procedure for progressive collapse analysis have been issued by the US General Service Administration (GSA) [15] and Department of Defense
(DoD) [16]. Sasani and Kazemi et al. carried out an experiment to evaluate potential progressive collapse of an actual 11-story reinforced concrete structure following the explosion of an exterior column [17]. Yi and He et al. conducted a static experiment on a four-bay three-story one-third scale planar frame to investigate progressive failure due to the loss of a lower story column [18]. Recently, experiments were carried out with RC beamcolumn sub-assemblages designed with and without seismic detailing $[19 \div 21]$. It was observed that seismically designed RC moment frames could resist progressive collapse by activation of beam catenary force at large displacement.

RC frame structures with specially shaped columns are frame structures or frame-shear wall structures in which traditional rectangular frame columns are replaced by + -shaped interior columns, T-shaped edge columns and L-shaped corner columns, as shown in Fig. 1. Width of column flanges and beams is imposed to be identical with corresponding walls so indoor prominent corners of columns can be avoided, resulting in a growth in usable floor area and convenience in indoor arrangement. There are also other advantages for frame structures with specially shaped columns such as reducing self-weight of the structure and saving in the material if lightweight material filler walls are used at the same time. Owing to these advantages, this kind of structure is widely used in multi-story and high-rise buildings in China. Experiments on specially shaped reinforced concrete frames and components have been carried out in recent years to study their seismic performance $[22,23]$. However, studies on 
progressive collapse performance of structures are mainly concentrated on frame structures with rectangular columns and rarely involve frame structures with specially shaped columns. The frame structures with specially shaped columns are widely adopted in residential structures which will cause serious losses of lives and properties once collapse occurs. Therefore, it is necessary to conduct a further research on the progressive collapse performance of frames with specially shaped columns.

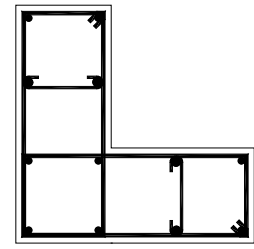

(a) L-shaped column

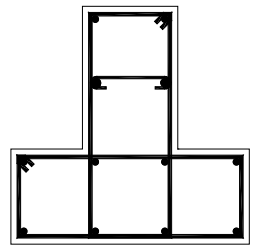

(b) T-shaped column

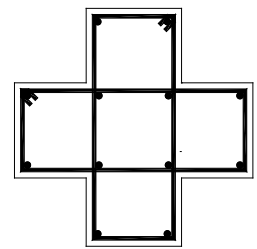

(c)+-shaped column
Figure 1 Specially shaped columns

The frame structures with specially shaped columns and the frame structures with rectangular columns are different types of structures with different column sections. There will be some similarities and differences between their progressive collapse resistances resulting from the differences of column section and mechanical properties. The accuracy of the finite element model was verified through comparing the test results with the calculation results. Then, progressive collapse resistance of frame structures with specially shaped columns was compared with that of frame structures with rectangular columns designed in accordance with the design codes of China under the same design and application conditions using nonlinear static analysis and nonlinear dynamic analysis based on the alternative path method [14]. The characteristics of progressive collapse performance of frame structures with specially shaped columns were studied.

\section{Model verification}

An accurate finite element model is the premise to use numerical simulation method for further study. In this paper, a progressive collapse analysis method was proposed using the beam-column element and joint element based on the computer program OpenSees [24]. Firstly, the feasibility of the model was verified using the experimental data of literature [18]. Then, the differences of progressive collapse resistance between frames with specially shaped columns and frames with rectangular columns were investigated.

\subsection{Finite element model}

The numerical model was developed by the finite element program OpenSees which had a better accuracy in the simulation of the nonlinear performance of reinforced concrete structures. The finite element model was a four-bay and three-story reinforced concrete frame structure which was identical with the test model in literature [18]. Fig. 2 depicts the details of the model frame and Tab. 1 summarizes the details of reinforcement. The yield strength of longitudinal reinforcement is 416
$\mathrm{MPa}$, and the ultimate tensile strength is $526 \mathrm{MPa}$. The yield strength of stirrup is $370 \mathrm{MPa}$ while the compressive strength of concrete is $25 \mathrm{MPa}$.
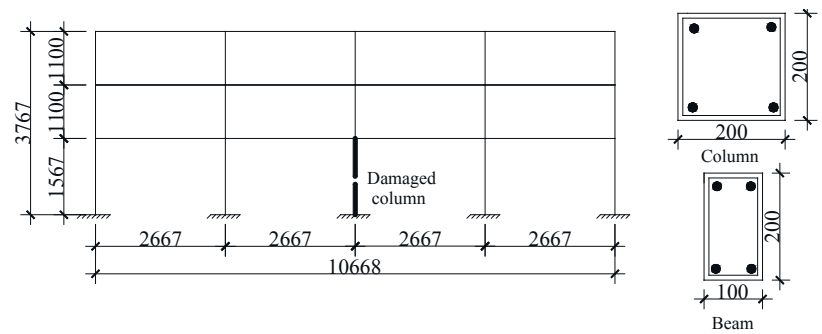

Figure 2 Details of model frame

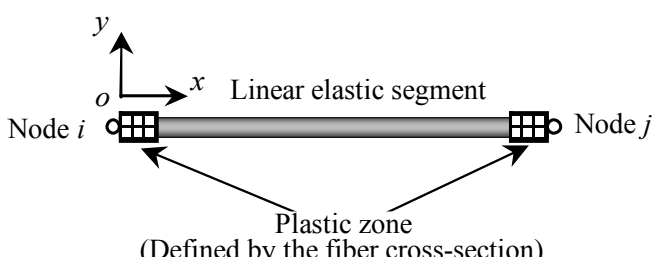

Figure 3 Component of beamWithHinges element

Table 1 Beam and column reinforcement

\begin{tabular}{|c|c|c|c|c|}
\hline \multicolumn{2}{|c|}{ Longitudinal reinforcement } & \multicolumn{2}{c|}{ Transverse reinforcement } \\
\hline \multirow{2}{*}{$\begin{array}{c}\text { Column } \\
(\mathrm{mm})\end{array}$} & \multicolumn{2}{|c|}{ Beam (mm) } & \multicolumn{2}{c|}{ Column and Beam } \\
\cline { 2 - 5 } & Top bar & Bottom bar & Diameter $(\mathrm{mm})$ & Space $(\mathrm{mm})$ \\
\hline 4D12 & 2D12 & 2D12 & 6 & 150 \\
\hline
\end{tabular}

In order to simulate the progressive collapse process of reinforced concrete frame accurately the beamWithHinges element based on the finite element flexibility method was used to simulate the beam and column of the frame [25]. As shown in Fig. 3, the beamWithHinges element is based on the non-iterative (or iterative) flexibility formulation, and considers plasticity to be concentrated over specified hinge lengths at the element ends in which the cross-section of a structural member is modelled by fibre element. For modelling of beam elements with considering catenary action the 'corotational' geometric transformation was used.

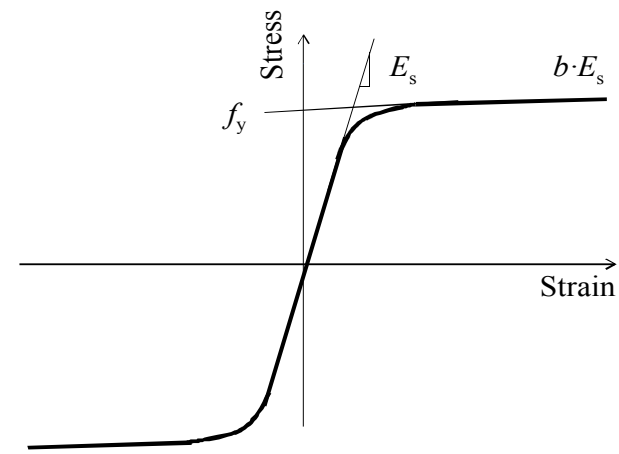

Figure 4 Stress-strain relationship of steel

The 'steel02' material was adopted in the finite model to model the stress-strain relationship of reinforcing bars. The monotonic loading curve of the stress-strain relationship was cared in the progressive collapse analysis while the hysteretic behaviour of material under earthquake was cared in seismic analysis. The envelope curve of the stress-strain relationship in tensile and compressive side is presented in Fig. 4. Tab. 2 
summarizes the parameter values to define reinforcing bars.

The 'concrete02' material as shown in Fig. 5 was applied in the computation to simulate the material properties of concrete accurately. There were two kinds of concrete: the core concrete confined by stirrup and the cover concrete (Unconfined Concrete). The core concrete was divided into 'Confined Concrete-1' (beams) and 'Confined Concrete-2' (columns) according to the section size and the reinforcement ratio of longitudinal reinforcement and the reinforcement ratio of transverse reinforcement, respectively. The softening effect of the tensile strength of concrete was not taken into account in cover concrete. The elasticity modulus of the softening stage of the tensile strength was assumed to be a very large number. The concrete cracks and the tensile strength reduces to zero rapidly after the tensile stress reaches the tensile strength limitation. Kent-Park model expanded by Scott et al. [26] was adopted to compute the skeleton curve of the confined concrete under compression. Tab. 3 shows the parameter values of defining the concrete material. The expression of every segment of the stressstrain relationship of concrete and the calculation of the key points refer to literature [24].

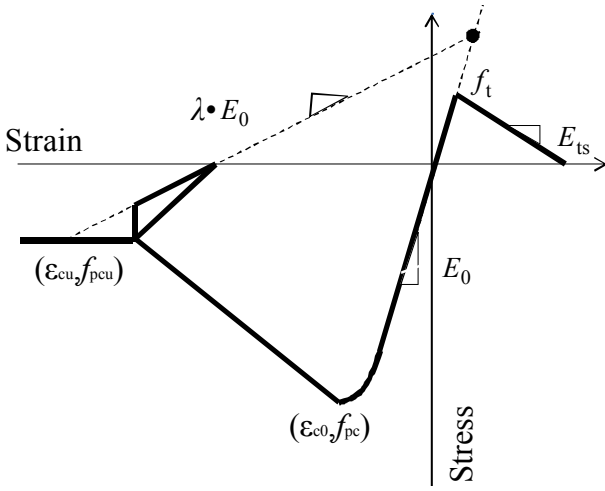

Figure 5 Stress-strain relationship of concrete

Table 2 Material properties of steel

\begin{tabular}{|c|c|c|c|c|c|c|c|c|c|c|}
\hline & $f_{v} / \mathrm{MPa}$ & $E_{s} / \mathrm{GPa}$ & $\mathrm{b}$ & $\mathrm{R} 0$ & $\mathrm{cR} 1$ & $\mathrm{cR} 2$ & $\mathrm{a} 1$ & $\mathrm{a} 2$ & $\mathrm{a} 3$ & $\mathrm{a} 4$ \\
\hline Longitudinal reinforcement & 416 & 200 & 0,005 & 17,5 & 0,925 & 0,15 & 0,0 & 1,0 & 0,0 & 1,0 \\
\hline Transverse reinforcement & 370 & 210 & 0,005 & 17,5 & 0,925 & 0,15 & 0,0 & 1,0 & 0,0 & 1,0 \\
\hline
\end{tabular}

Table 3 Material properties of concrete

\begin{tabular}{|c|c|c|c|c|c|c|c|}
\hline & $f_{\mathrm{pc}} / \mathrm{MPa}$ & $\varepsilon_{c 0}$ & $f_{\mathrm{pcu}} / \mathrm{MPa}$ & $\varepsilon_{c u}$ & $\lambda$ & $f_{\mathrm{t}} / \mathrm{MPa}$ & $E_{\mathrm{ts}} / \mathrm{MPa}$ \\
\hline Confined Concrete-1 & $-28,20$ & $-0,0022$ & $-5,64$ & $-0,012$ & 0,25 & 2,61 & 7350 \\
\hline Confined Concrete-2 & $-26,74$ & $-0,0021$ & $-5,35$ & $-0,011$ & 0,25 & 2,61 & 7350 \\
\hline Unconfined Concrete & $-25,0$ & $-0,0020$ & $-5,00$ & $-0,004$ & 0,25 & 2,61 & $\mathrm{INT}$ \\
\hline
\end{tabular}

Note: INT represents a very large number.

Fig. 6 shows the beam-ColumnJoint element used to simulate the beam-column joints. This model includes one shear-panel component that is intended to simulate strength and stiffness loss associated with shear failure of the joint core, eight bar-slip components that are intended to simulate stiffness and strength loss associated with bond strength deterioration for beam and column longitudinal reinforcement embedded in the joint core and four interface-shear components that are intended to simulate loss of shear-transfer capacity at the joint-beam and joint-column perimeter under severe loading of the joint. Three kinds of uniaxial materials were adopted to model the above three categories of springs, respectively.

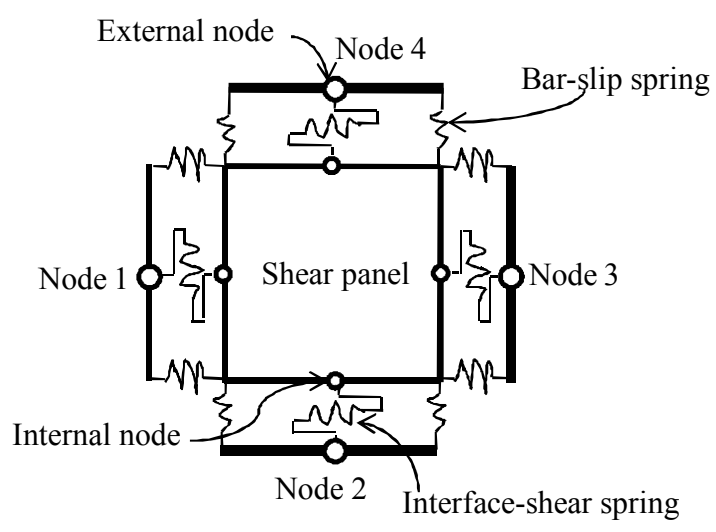

Figure 6 Component of beam-ColumnJoint

It was found in the pilot calculation process that the interface-shear springs were in elastic stage and the deformation was small. For simplicity, the interface-shear springs were defined to be an elastic material and the shear deformation at the joint-beam and joint-column perimeter was ignored. The bar-slip springs were modelled with 'BarSlip' material. The shear-panel spring was modelled with 'Pinching4' material. The main parameters of defining this material are the key points of the material response envelope curve under monotonic loading, as shown in Fig. 7. The 4 points of the first quadrant are symmetric with that of the third quadrant. These points can be calculated based on the modified compression field theory proposed by Vecchio and Collins [27]. Tab. 4 summarizes the values of these points.

Table 4 Key points on shear panel spring skeleton curve

\begin{tabular}{|c|c|c|c|c|c|c|c|}
\hline \multicolumn{2}{|c|}{$\begin{array}{c}\text { Point } 1 \\
(d 1, f 1)\end{array}$} & \multicolumn{2}{c|}{$\begin{array}{c}\text { Point } 2 \\
(d 2, f 2)\end{array}$} & \multicolumn{2}{c|}{$\begin{array}{c}\text { Point } 3 \\
(d 3, f 3)\end{array}$} & \multicolumn{2}{c|}{$\begin{array}{c}\text { Point } 4 \\
(d 4, f 4)\end{array}$} \\
\hline Strain & $\begin{array}{c}\text { Stress } \\
/ \mathrm{MPa}\end{array}$ & Strain & $\begin{array}{c}\text { Stress } \\
/ \mathrm{MPa}\end{array}$ & Strain & $\begin{array}{c}\text { Stress } \\
/ \mathrm{MPa}\end{array}$ & Strain & $\begin{array}{c}\text { Stress } \\
/ \mathrm{MPa}\end{array}$ \\
\hline 0,00021 & 0,931 & 0,0039 & 2,38 & 0,028 & 3,51 & 0,037 & 0,453 \\
\hline
\end{tabular}

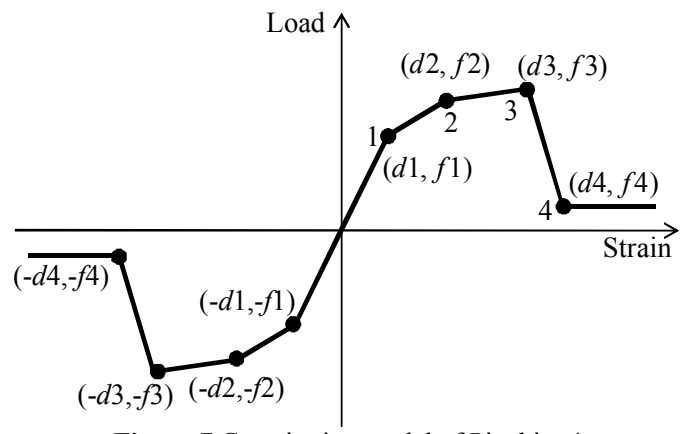

Figure 7 Constitutive model of Pinching4 


\subsection{Comparison of test and analytical results}

The finite element model was set up using the above beam-column element and joint element. The analytical relationship curve between the axial force and unloading displacement of the middle column and the analytical relationship curve between the horizontal displacement and unloading displacement of the middle column were compared with the experimental results of literature [18] in Figure 8. It was observed from the results that the results of the analytical model set up with beamWithHinges element and beam-ColumnJoint element are in good agreement with the experimental results. So, the analytical model based on beamWithHinges element and beam-ColumnJoint element can predict the mechanical and deformation properties of reinforced concrete frame structures well in the progressive collapse process when catenary action was considered. These two kinds of elements were applied in the subsequent analysis in order to obtain more accurate analysis results.

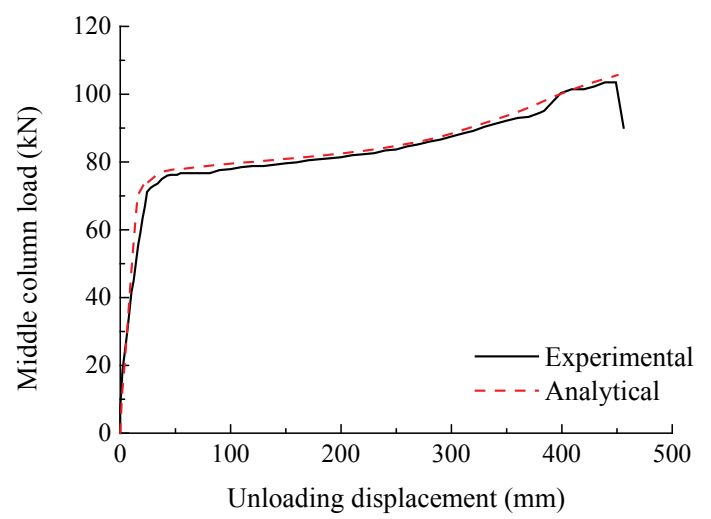

(a)

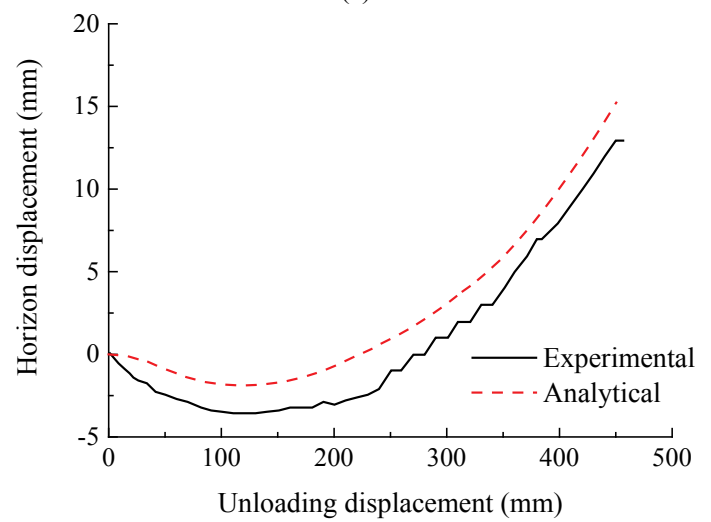

(b)

Figure 8 Comparison of results obtained by experiment and numerical simulation: (a) Relationship curve between axial force and unloading displacement of the middle column (b) Relationship curve between horizontal displacement and unloading displacement of the middle column

\section{Design of analysis model \\ 3.1 Structural model}

RC frame structures with specially shaped columns are mainly adopted in residential buildings. According to the requirements of residential buildings, a six-story frame structure with specially shaped columns (named SS) was designed in accordance with the design codes of China. The building was assumed to be located in the region with seismic fortification intensity 7 . The layout of the building is shown in Fig. 9. Progressive collapse analysis of the internal planar frame taken out of the twobay by two-bay frame structure was carried out. Figure 10 depicts the sectional dimension of the columns. The width of the limb is all $200 \mathrm{~mm}$, and the ratio between sections length and width is not beyond 4 .

In order to compare the progressive collapse resistance of frames with specially shaped columns with that of frames with rectangular columns under the same seismic fortification, design and application conditions, three kinds of frames with rectangular columns were designed in accordance with three different principles which were named SR1, SR2 and SR3, respectively. The column sections of frame SR1 has the same moment of inertia with the column sections of specially shaped columns. The column sections of SR2 has the same crosssectional area with the column sections of specially shaped columns. The column sections of frame SR3 has the same external size and reinforcement with the column sections of specially shaped columns. In other words, the specially shaped columns can be formed by cutting the outstanding edges and merging the reinforcing bars of the column sections of frame SR3. In order to increase the comparability, other design and application conditions of these four kinds of frame structures are identical. The cross-section of the beam is $200 \times 500 \mathrm{~mm}$. The thickness of the slab is $100 \mathrm{~mm}$. Strength level of the concrete in beams, slabs, and columns is C30. $335 \mathrm{MPa}$ grade reinforcement and $235 \mathrm{MPa}$ grade reinforcement are used in longitudinal reinforcement and transverse reinforcement, respectively. The design dead and live loads of the roof are $4,5 \mathrm{kN} / \mathrm{m}^{2}$ and $2,0 \mathrm{kN} / \mathrm{m}^{2}$, while that of the first floor and the standard floor are $4,0 \mathrm{kN} / \mathrm{m}^{2}$ and $2,0 \mathrm{kN} / \mathrm{m}^{2}$, respectively. The dead load of infill wall imposed on the beam is $5 \mathrm{kN} / \mathrm{m}$.
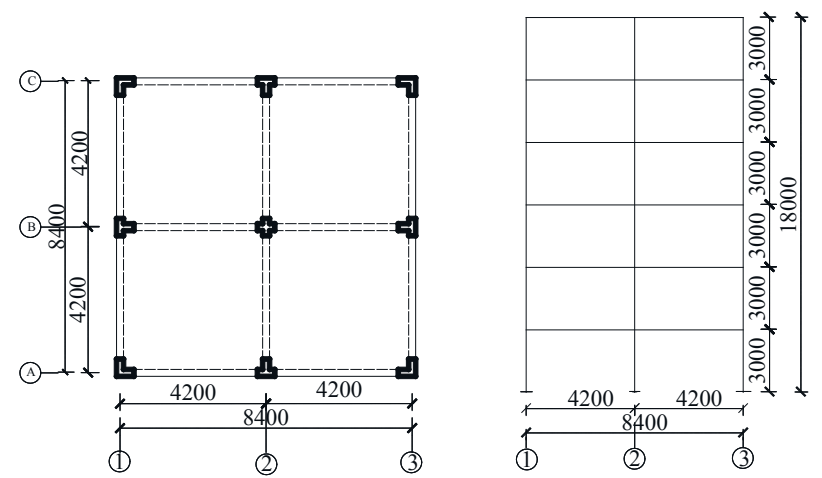

Figure 9 Layout of frame with specially shaped columns
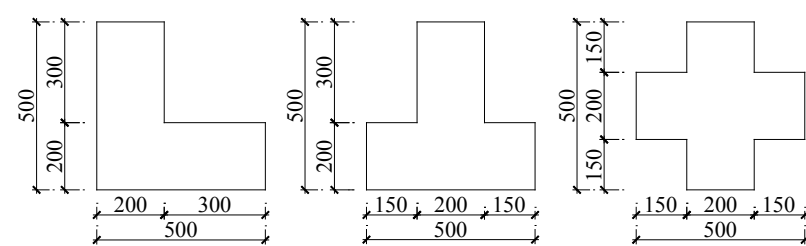

Figure 10 Section dimension of specially shaped columns

Calculation of the internal force and reinforcement of these four kinds of structures were carried out to determine the sectional dimensions and reinforcement of the columns and beams. Tab. 5 presents the sectional dimensions and reinforcement details of planar frames on which progressive collapse analysis will be performed. 
Table 5 Dimension and reinforcement of the columns and beams

\begin{tabular}{|c|c|c|c|c|c|}
\hline \multirow{2}{*}{ Structure } & Structural members & Sectional dimension $(\mathrm{mm})$ & $\begin{array}{c}\text { Reinforcement } \\
(\mathrm{mm})\end{array}$ & Section area $\left(\mathrm{cm}^{2}\right)$ & Reinforcement ratio $(\%)$ \\
\hline \multirow{2}{*}{ SS } & Exterior Column & T: $200 \times 500$ & $12 \mathrm{D} 16$ & 1600 & 1,51 \\
\cline { 2 - 6 } & Interior Column & $+: 200 \times 500$ & $12 \mathrm{D} 16$ & 1600 & 1,51 \\
\hline \multirow{2}{*}{ SR1 } & Exterior Column & $391 \times 458$ & $8 \mathrm{D} 16$ & 1790 & 0,90 \\
\cline { 2 - 6 } & Interior Column & $407 \times 407$ & $8 \mathrm{D} 16$ & 1656 & 0,97 \\
\hline \multirow{2}{*}{ SR2 } & Exterior Column & $400 \times 400$ & $8 \mathrm{D} 16$ & 1600 & 1,01 \\
\cline { 2 - 6 } & Interior Column & $400 \times 400$ & $12 \mathrm{D} 16$ & 1600 & 1,01 \\
\hline \multirow{2}{*}{ SR3 } & Exterior Column & $500 \times 400$ & $12 \mathrm{D} 16$ & 2500 & 0,96 \\
\cline { 2 - 6 } & Interior Column & $500 \times 400$ & $\begin{array}{c}\text { Top: 3D20 } \\
\text { Bottom: 2D20 }\end{array}$ & 1000 & 0.96 \\
\hline SS SR1 & Beam & $200 \times 500$ & & & 1,57 \\
\hline
\end{tabular}

\subsection{Finite element model}

The finite element models of these four kinds of frames were set up using beamWithHinges element and beam-ColumnJoint element mentioned previously. Concrete of beams and columns was modelled by 'concrete02' material. The material parameters of confined concrete such as the peak stress and peak strain were calculated with the formula proposed by Kent-Park, as shown in Tab. 6. Stress-strain relationship of the reinforcing bars was modelled with 'steel02' material. Tab. 7 presents the parameter values of defining steel material.

Table 6 Material properties of confined concrete

\begin{tabular}{|c|c|c|c|c|c|c|c|c|}
\hline Structure & Structural members & $f_{\mathrm{pc}}(\mathrm{MPa})$ & $\varepsilon_{c 0}$ & $f_{\mathrm{pcu}}(\mathrm{MPa})$ & $\varepsilon_{c u}$ & $\lambda$ & $f_{\mathrm{t}}(\mathrm{MPa})$ & $E_{\mathrm{ts}}(\mathrm{MPa})$ \\
\hline \multirow{2}{*}{$\mathrm{SS}$} & Exterior Column & $-29,20$ & $-0,0022$ & $-5,84$ & $-0,0232$ & 0,25 & 2,61 & 6598 \\
\cline { 2 - 9 } & Interior Column & $-30,51$ & $-0,0023$ & $-6,10$ & $-0,0273$ & 0,25 & 2,61 & 6598 \\
\hline \multirow{2}{*}{ SR1 } & Exterior Column & $-28,46$ & $-0,0022$ & $-5,69$ & $-0,0240$ & 0,25 & 2,61 & 6598 \\
\cline { 2 - 9 } & Interior Column & $-28,56$ & $-0,0022$ & $-5,71$ & $-0,0252$ & 0,25 & 2,61 & 6598 \\
\hline \multirow{2}{*}{ SR2 } & Exterior Column & $-28,61$ & $-0,0022$ & $-5,72$ & $-0,0255$ & 0,25 & 2,61 & 6598 \\
\cline { 2 - 9 } & Interior Column & $-28,61$ & $-0,0022$ & $-5,72$ & $-0,0255$ & 0,25 & 2,61 & 6598 \\
\hline \multirow{2}{*}{ SR3 } & Exterior Column & $-28,04$ & $-0,0021$ & $-5,61$ & $-0,0229$ & 0,25 & 2,61 & 6598 \\
\cline { 2 - 9 } & Interior Column & $-28,04$ & $-0,0021$ & $-5,61$ & $-0,0229$ & 0,25 & 2,61 & 6598 \\
\hline SS SR1 & Beam & $-29,98$ & $-0,0023$ & $-5,99$ & $-0,0254$ & 0,25 & 2,61 & \multirow{2}{*}{6598} \\
\hline
\end{tabular}

Table 7 Material properties of steel

\begin{tabular}{|c|c|c|c|c|c|c|c|c|c|c|}
\hline & $f_{v} / \mathrm{MPa}$ & $E_{\mathrm{s}} / \mathrm{GPa}$ & $\mathrm{b}$ & $\mathrm{R} 0$ & $\mathrm{cR} 1$ & $\mathrm{cR} 2$ & $\mathrm{a} 1$ & $\mathrm{a} 2$ & $\mathrm{a} 3$ & $\mathrm{a} 4$ \\
\hline Longitudinal reinforcement & 388,3 & 200 & 0,005 & 18,5 & 0,925 & 0,15 & 0,0 & 1,0 & 0,0 & 1,0 \\
\hline Transverse reinforcement & 272,4 & 210 & 0,005 & 18,5 & 0,925 & 0,15 & 0,0 & 1,0 & 0,0 & 1,0 \\
\hline
\end{tabular}

\section{Progressive collapse analysis of the structure 4.1 Nonlinear static analysis}

Nonlinear static analyses were performed to investigate the responses of frames subjected to sudden loss of a first-story column under the vertical load. The analyses were carried out until the vertical deflection over beam length became $0,2 \mathrm{rad}$, in consideration of the fact that the test specimens of Sasani and Kropelnicki and Yi et al. $[18,28]$ failed at a beam deflection of about 0,195 rad. It was calculated that the vertical ultimate displacement of the failure point was $850 \mathrm{~mm}$ when a first-story column was removed. Load imposed on structure at this time was defined as the progressive collapse-resisting capacity of structure.

Figure 11 presents the nonlinear static analysis results of the frames when a first-story column was removed. It can be seen from the results that the bearing capacity of frame SR3 is the biggest which is higher than that of frame SS, and the bearing capacity of frame SR1 and SR2 is lower than the bearing capacity of frame SS. Meanwhile, the bearing capacities of these four kinds of frames are all lower than the loading state specified in the GSA guideline including the dynamic amplification factor $(2 \times($ dead load $+0,25 \times$ live dead $))$ which illustrates that these four kinds of frames all have the potential of progressive collapse. The bearing capacity of frame SS is just decreased by $2,15 \mathrm{kN} / \mathrm{m}$ (about $3 \%$ ) compared with that of frame SR3. It can be observed that their deformation and bearing capacities are similar when progressive collapse analysis mainly considers the vertical load. Because their beams are exactly the same and the columns have the same reinforcement, although their forms of column sections are different. At the same time, the frame with specially shaped columns has a smaller column section area which effectively reduces the structure weight (weight of column decreased by $56 \%$ ). The differences resulting from different column sections are further made up.

The frame beam was in cantilever state when an exterior column was removed. When the deformation is small, edge region of the frame structure resists progressive collapse with the flexural capacity of frame beam ends which leads to curve SS and curve SR3 almost coincide before the vertical displacement reaches approximately $250 \mathrm{~mm}$. The results show that frame SS and frame SR3 have the same ability to resist progressive collapse at this time. The capacity of frame SR3 will continue to rise due to the stronger deformation capacity and reinforced anchoring ability of the joint with vertical 
displacement over $250 \mathrm{~mm}$. However, the structure begins to damage and the bearing capacity begins to decline due to the weakness of the joint of frame with specially shaped columns.

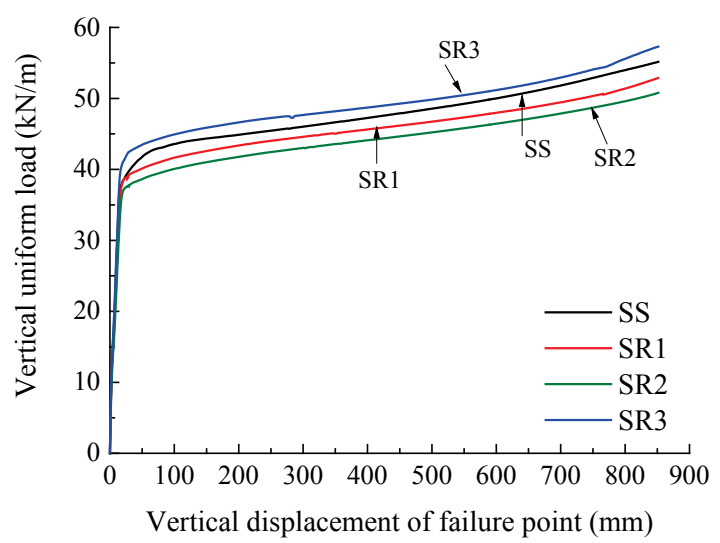

(a) Interior column failure

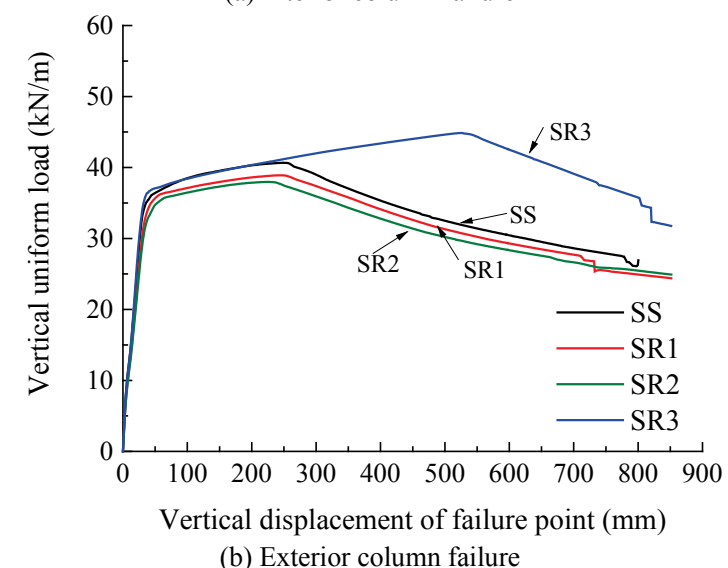

Figure11 Vertical load-displacement curve of failure point

The frame with specially shaped columns designed in accordance with related codes that meets the requirements of normal use has a similar progressive collapse resistance compared with frame with rectangular columns in the same seismic fortification area. It is because the design codes for designing frames with specially shaped column will be more stringent due to their irregular shape, more complex and unfavourable mechanical behaviour. Progressive collapse resistance of frame SR1 and frame SR2 are less than that of frame SS, since their reinforcement is less than that of frame SS. The strict requirement of design codes for designing frames with specially shaped columns can make frames with specially shaped columns have a similar or better performance to resist progressive collapse compared with frames with rectangular columns.

\subsection{Nonlinear dynamic analysis}

The instantaneous loading method was applied to investigate the dynamic responses of structures when one of the columns was removed. Nonlinear dynamic analysis involves the following steps:

1. Perform nonlinear static analysis of the structure under gravity loads to obtain the internal forces in the column to be removed.

2. Remove the damaged column and apply the internal forces $P_{0}(M, N$ and $V)$ obtained in the previous step to the remaining structure, along with the gravity loads. Note that the results of such analysis are identical to those of the previous analysis, where the column was not removed.

3. Perform nonlinear dynamic analysis of the structure under the forces changed with time in the opposite direction to the forces applied to the structure at the top of removed column.

Load-applied process is shown in Fig. 12. Load combinations applied on frame are defined by the following formula:

$$
L O A D=D L+0,25 L L
$$

where $D L$ is dead load, and $L L$ is live load.

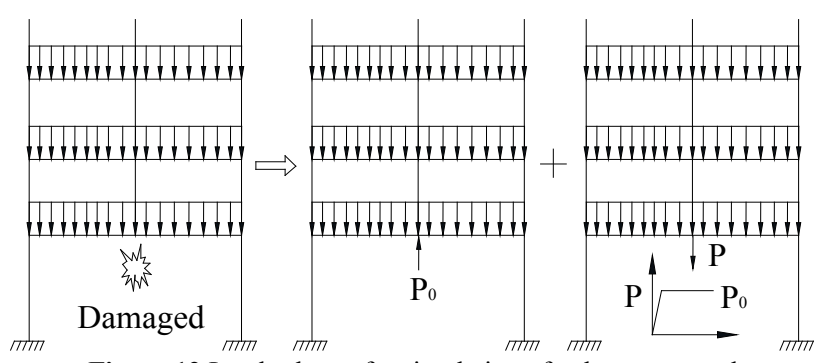

Figure 12 Load scheme for simulation of column removal

In the structural dynamic analysis, it is necessary to determine the damping. In this paper, Rayleigh damping was used, following:

$[\boldsymbol{C}]=\alpha[\boldsymbol{M}]+\beta[\boldsymbol{K}]$

where $[\boldsymbol{C}]$ is structural damp matrix, $[\boldsymbol{M}]$ is the structural mass matrix, $[\boldsymbol{K}]$ is the structural stiff matrix, $\alpha$ is mass damping coefficient, $\beta$ is stiff damping coefficient. The two coefficients can be obtained from Eq. (3) and (4), respectively.

$\alpha=\frac{2 \omega_{i} \omega_{j}\left(\xi_{i} \omega_{j}-\xi_{j} \omega_{i}\right)}{\omega_{j}^{2}-\omega_{i}^{2}}$

$\beta=\frac{2\left(\xi_{j} \omega_{j}-\xi_{i} \omega_{i}\right)}{\omega_{j}^{2}-\omega_{i}^{2}}$

where $\omega_{i}$ and $\omega_{j}$ are $i^{\text {th }}$ and $j^{\text {th }}$ natural frequency of the structure. $\xi_{i}$ and $\xi_{j}$ are the damping ratio of $i^{\text {th }}$ and $j^{\text {th }}$ vibration mode. In this paper, the damping ratio of the reinforced concrete was set to be 0,05 and corresponding vibration modes were selected as the first and second mode of the structure.

The vertical displacement time history curves of failure points when an interior column was removed are shown in Fig. 13(a). It can be observed from the results that the deformation of frames is small under the applied load. The vertical displacement of failure point of frame SS is minimal $(12,91 \mathrm{~mm})$, while structure SR2 has the maximum deformation whose displacement is $18,2 \mathrm{~mm}$. At this moment, the whole structure is still in elastic deformation stage and the progressive collapse resistance of structure is mainly provided by the frame beam. The vertical deformation of frame SR3 is a little larger $(15,4$ $\mathrm{mm}$ ) since the self-weight of structure is larger while the reinforcement of frame SS and SR3 and the load applied 
on beam are completely identical. The vertical displacement of frame SR3 increases by $2,8 \mathrm{~mm}$ compared with that of frame SS. Meanwhile the vertical displacements of failure point of these four kinds of frames are far less than the allowable displacement for nonlinear analysis specified in the GSA guideline. It illustrates that progressive collapse of these four kinds of frames will not occur. These results are different from the nonlinear static analysis results which illustrate that dynamic amplification factor of 2,0 for nonlinear static analysis is conservative.

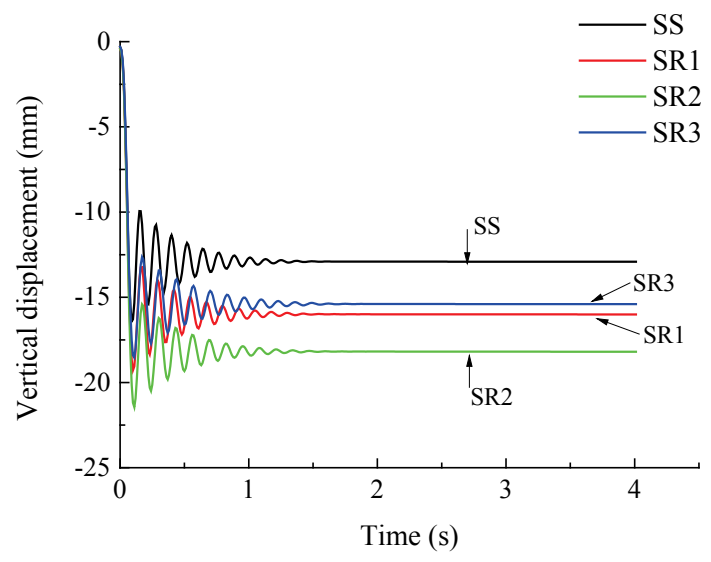

(a) Interior column failure

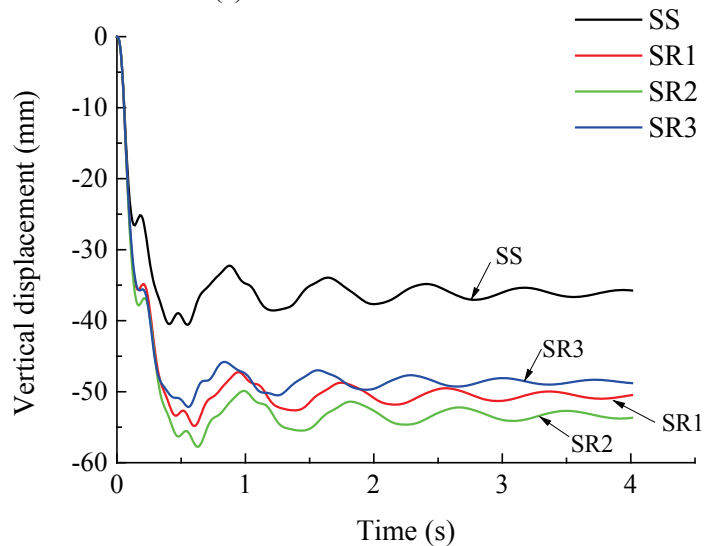

(b) Exterior column failure

Figure 13 Vertical displacement time history curves of failure point

Fig. 13(b) is the vertical displacement time history curves of failure point when an exterior column was removed. The results correspond well with the curves obtained above when an interior column was removed. The vertical deformation of frame SR3 is slightly larger since the self-weight of structure is larger when the whole structure is still in the elastic deformation stage and the progressive collapse resistance of frame is mainly provided by frame beam.

\section{Conclusion}

Three kinds of frames with rectangular columns were designed in accordance with three different principles. Nonlinear static analysis and nonlinear dynamic analysis were performed to compare the progressive collapse resistance of frame structures with specially shaped columns with that of frame structures with rectangular columns under the same seismic fortification, design and application conditions. The following conclusions were drawn based on observations and findings from the analysis described in this paper.

1. Progressive collapse characteristics of the reinforced concrete frame structures can be well predicted using the element, stress-strain relationships and modelling method used in this paper based on the computer program OpenSees.

2. Nonlinear static analysis results show that these four kinds of frames have the potential of progressive collapse when an exterior or interior column was removed. The frames with specially shaped columns and the frames with rectangular columns with the same reinforcement have a similar progressive collapse resistance.

3. Nonlinear dynamic analysis results show that progressive collapse of these four kinds of frames will not occur when a lower story column was removed which illustrates that dynamic amplification factor of 2,0 for nonlinear static analysis is conservative.

4. The frames with rectangular columns with the same moment of inertia and cross-sectional area have a lower progressive collapse resistance compared with frames with specially shaped columns. The strict requirement of the design codes for designing frames with specially shaped columns makes the frame with specially shaped columns have a superior performance to resist progressive collapse.

\section{Acknowledgements}

This research is supported by the Natural Science Foundation of China (No. 51178304). The authors would like to express sincere gratitude to Meng, T., Yang, Z. J., Wang, W. J., Liu, X., Zhang, L. and Prof. Shuang Li for providing the assistance during the research

\section{References}

[1] Structural Engineering Institute. Minimum Design Loads for Buildings and Other Structures. ASCE Publications, 2006.

[2] Kotsovinos, P.; Usmani A. The World Trade Center 9/11 disaster and progressive collapse of tall buildings. // Fire technology. 49, 3(2013), pp. 741-765. DOI: 10.1007/s10694012-0283-8

[3] Xu, G.; Ellingwood, B. R. An energy-based partial pushdown analysis procedure for assessment of disproportionate collapse potential. // Journal of Constructional Steel Research. 67, 3(2011), pp. 547-555. DOI: 10.1016/j.jcsr.2010.09.001

[4] Kim, J.; Park, J. H.; Lee, T. H. Sensitivity analysis of steel buildings subjected to column loss. // Engineering Structures. 33, 2(2011), pp. 421-432. DOI: 10.1016/j.engstruct.2010.10.025

[5] Alashker, Y.; Li, H.; El-Tawil, S. Approximations in progressive collapse modeling. // Journal of Structural Engineering. $137,9(2011)$, pp. 914-924. DOl: 10.1061/(ASCE)ST.1943-541X.0000452

[6] Mohamed, O. A. Progressive collapse of structures: annotated bibliography and comparison of codes and standards. // Journal of performance of constructed facilities. $\quad 20, \quad 4(2006)$, pp. 418-425. DOI: 10.1061/(ASCE)0887-3828(2006)20:4(418)

[7] Nair, R. S. Preventing disproportionate collapse. // Journal of Performance of Constructed Facilities. 20, 4(2006), pp. 309-314. DOI: 10.1061/(ASCE)0887-3828(2006)20:4(309) 
[8] Ellingwood, B. R. Mitigating risk from abnormal loads and progressive collapse. // Journal of Performance of Constructed Facilities. 20, 4(2006), pp. 315-323. DOI: 10.1061/(ASCE)0887-3828(2006)20:4(315)

[9] Dusenberry, D. O.; Juneja, G. Review of existing guidelines and provisions related to progressive collapse // Workshop on Prevention of Progressive Collapse. 2002.

[10] Ellingwood, B. R.; Smilowitz, R.; Dusenberry, D. O. et al. Best practices for reducing the potential for progressive collapse in buildings. US Department of Commerce, National Institute of Standards and Technology, 2007. DOI: 10.6028/NIST.IR.7396

[11] Starossek, U. Progressive collapse of structures: Nomenclature and procedures. // Structural Engineering International. 16, 2(2006), pp. 113-117. DOl: 10.2749/101686606777962477

[12] Starossek, U.; Wolff, M. Progressive collapse: Design strategies. // IABSE Symposium Report. International Association for Bridge and Structural Engineering. 90, 8(2005), pp. 9-16. DOI: 10.2749/222137805796270829

[13] Marjanishvili S.; Agnew E. Comparison of various procedures for progressive collapse analysis. // Journal of Performance of Constructed Facilities. 20, 4(2006), pp. 365-374. DOI: 10.1061/(ASCE)0887-3828(2006)20:4(365)

[14] Marjanishvili, S. M. Progressive analysis procedure for progressive collapse. // Journal of Performance of Constructed Facilities. 18, (2004), pp. 79-85. DOl: 10.1061/(ASCE)0887-3828(2004)18:2(79)

[15] General Services Administration (GSA). Progressive collapse analysis and design guidelines for new federal office buildings and major modernization projects, 2003.

[16] Department of Defense (DOD). Design of buildings to resist progressive collapse. Unified Facilities Criteria (UFC) 4-023-03, 27 January, 2010

[17] Sasani, M.; Kazemi, A.; Sagiroglu, S. et al. Progressive collapse resistance of an actual 11-story structure subjected to severe initial damage. // Journal of Structural Engineering. 137, 9(2011), pp. 893-902. DOl: 10.1061/(ASCE)ST.1943-541X.0000418

[18] Yi, W. J.; He, Q. F.; Xiao, Y. et al. Experimental study on progressive collapse-resistant behavior of reinforced concrete frame structures. // ACI Structural Journal. 105, 4(2008), pp. 433-439.

[19] Su, Y.; Tian, Y.; Song, X. Progressive collapse resistance of axially-restrained frame beams. // ACI Structural Journal. 106, 5(2009), pp. 600-607.

[20] Choi, H.; Kim, J. Progressive collapse-resisting capacity of RC beam-column sub-assemblage. // Magazine of Concrete Research. 63, 4(2011), pp. 297-310. DOI: 10.1680/macr.9.00170

[21] Yu, J.; Tan, K. H. Experimental and numerical investigation on progressive collapse resistance of reinforced concrete beam column sub-assemblages. // Engineering Structures. 55(2013), pp. 90-106. DOl: 10.1016/j.engstruct.2011.08.040

[22] Wang, T.; Zhang, X. Frame property of unequal storey height with specially shaped columns under cyclic loading. // Journal of Central South University of Technology. 17, 6(2010), pp. 1364-1369. DOI: 10.1007/s11771-010-0643-9

[23] Wang, T. C.; Liu, X.; Zhao, H. L. Experimental Study of the Seismic Performance of L-Shaped Columns with 500 MPa Steel Bars. // The Scientific World Journal, 2014. DOI: 10.1155/2014/105826

[24] OpenSees. Open System for Earthquake Engineering Simulation, Pacific Earthquake Engineering Research Center, University of California, Berkeley, California, http://opensees.berkeley.edu, (accessed: 8-11-2013).

[25] Li, S.; Zhai, C. H.; Xie, L. L. Evaluation of displacementbased, force-based and plastic hinge elements for structural non-linear static analysis. // Advances in Structural
Engineering. 15, 3(2012), pp. 477-488. DOI: 10.1260/13694332.15.3.477

[26] Scott, B. D.; Park, R.; Priestley, M. J. N. Stress-strain behavior of concrete confined by overlapping hoops at low and high strain rates. // ACI Journal Proceedings. 79, 1(1982), pp. 13-27.

[27] Vecchio, F. J.; Collins, M. P. The modified compressionfield theory for reinforced concrete elements subjected to shear. // ACI Journal Proceedings. 83, 2(1986), pp. 219231.

[28] Sasani, M.; Kropelnicki, J. Progressive collapse analysis of an RC structure. // The Structural Design of Tall and Special Buildings. 17, 4(2008), p. 757-771. DOl: 10.1002/tal.375

\section{Authors' addresses}

\section{Qingwei Chen, Ph.D.}

Economic \& Technology Research Institute of State Grid Shandong Electric Power Company,

111 Weishi Road, Huaiyin District, Jinan, 250021, China chenqingwei@tju.edu.cn

Hailong Zhao, Lecturer (Corresponding author) School of Civil Engineering, Tianjin University Key Laboratory of Coast Civil Structure Safety (Tianjin University), Ministry of Education,

92 Weijin Road, Nankai District, Tianjin, 300072, China hlongzhao_tju@163.com

\section{Tiecheng Wang, professor}

School of Civil Engineering, Tianjin University Key Laboratory of Coast Civil Structure Safety (Tianjin University), Ministry of Education, 92 Weijin Road, Nankai District, Tianjin, 300072, China tcwang_tju@163.com 